\title{
Research on Application of seepage control prevention Earthwork synthetic material on earth rock dam
}

\author{
Ying gao $^{1, \text { a }}$ \\ ${ }^{1}$ Xijing University,xian, 710000,china \\ a 394686680@qq.com
}

Xijing University research, project number: XJ130232

Keywords: geosynthetics ; earth dam; seepage prevention

\begin{abstract}
With the development of construction technology, Earthwork synthetic material is a very promising new type on dam materials, which is the more and more widely used. It has seepage control and drainage, filtration, isolation, protection and other functions, especially in the earth dam seepage control applications. Earthwork synthetic material played a save the effect of project investment, shorten the construction period, which is worth popularizing in earth-rock dam engineering widespread use.
\end{abstract}

\section{Introduction}

Geosynthetic material is geotextile and geomembrane, made of synthetic polymers (including all kinds of plastic, synthetic fiber, synthetic rubber) as the raw material. Geosynthetic materials have advantages of light weight, good entirety, product standardization, high strength, strong corrosion resistance, easy transportation and storage and transportation, construction simple, which are used in earth dam project can get the result of saving project investment, shorten the construction period. Geosynthetic materials as a new type of dam is a very promising material with multiple functions of the seepage control and drainage, filtration, reinforcement, isolation and protection etc. With the increasingly extensive application, its variety is continuously increased, and the quality performance have a great improvement.

Commonly seen geosynthetic materials are polypropylene, polyethylene (PE), polyvinyl chloride (PVC), chlorinated polyethylene (CPE), chloroprene rubber (EPDM), and high density polyethylene (HDPE) and so on. It is generally divided into four categories. The first kind is geotechnical fabric (cloth), permeable, most raw material for polypropylene, polyester, followed by nylon and other synthetic fiber for approval. According to the manufacturing process it can be divided into different with fabric and nonwoven fabric, which can be used as a filter, reinforcement, isolation, drainage, protection purposes on the water conservancy project. The second category is the geosynthetic made of varieties of plastic, synthetic rubber, asphalt etc. that mainly used as seepage control material in the water conservancy project. The third class is a composite geosynthetic materials, made from two or more of the geotextiles, a mix of geomembrane. Finally is special geosynthetic materials, which is a new product developed in recent years, mainly including fabric and so on, in order to satisfy different engineering purposes.

Geotextile was used instead of natural sand filter layer in Florida revetment engineering in 
1958 for the first time. Geomembrane was the first with the upstream dam surface seepage control earthwork film in1959 Italian Contrada Subetta rock fill dam. The two projects set a precedent in projects of water conservancy engineering application. Geosynthetic materials have instead of natural building materials in thousands of the world's engineering application, playing a role of filter, reinforcement and seepage control, isolation, drainage, and so on in 40 years.

\section{The seepage control types of composite geomembrane}

For composite geomembrane in the dam body seepage control design of the function is different, anti-seepage structure type is different, and the stress and deformation of the membrane is also different, details are shown in table 1. In type selection should be according to the overall design requirements and the local engineering hydrology and weather, topography, hydrology and other natural conditions, combined with different composite geomembrane anti-seepage applicable conditions, advantages and disadvantages of various types, the size, form and materials of the seepage control engineering is chosen through fully demonstration.

Table 1 Compare of two kinds of characteristic

\begin{tabular}{|c|c|c|c|}
\hline \multirow{2}{*}{ Type } & \multicolumn{3}{|c|}{ content } \\
\cline { 2 - 4 } & location & Scope & shape \\
\hline Core wall & Dam internal & Joint antiseepage & Horizontal and vertical \\
\hline Inclined wall & Dam upstream & Independent impervious & horizontal \\
\hline
\end{tabular}

Core wall type geomembrane can be used in sandy pebble, sand dams and rock fill dam, and the seepage control structure is relatively simple. Composite geomembrane is a kind of polymer, which is aging under ultraviolet light. Composite geomembrane embedded is buried in the dam, with service life is long, but not easy to repair. Heart wall geomembrane can be used with other joint seepage control. For seepage control material for anti-seepage earth material defects, its seepage control ability is not high, if separately used as impervious body. Therefore, setting the composite geomembrane in upstream of anti-seepage wall soil heart improves the efficiency of the dam body seepage control or reduce the risk of local failure.

Inclined wall geomembrane service life is shorter than that of core wall type, but after aging or damage easy to repair, a layer of composite geomembrane. Inclined wall geomembrane anti-seepage is appropriate to independent used, generally not associated with viscous anti-seepage materials anti-seepage. The reason is that if the membrane after filling viscous soil or weak water permeability of soil, so dam slope of earth-rock dam should be slow to increase investment, while the upstream water level drop water not easy flowing rapidly through the defect in the membrane, membrane by reverse osmotic pressure prone to instability, in that case need to set up a special drainage facilities. But part of the dam body renovation project satisfied seepage control, seepage stability of dam slope and slope protection as a combination of homogeneous earth dam seepage control regulation or as part of heightening reservoir seepage control can connect with the original anti-seepage wall.

\section{The seepage control design of composite geomembrane}

In a composite geomembrane impervious body construction, the difference of geomembrane anti-seepage type varies. But it mainly includes base and cushion construction, composite geomembrane laying and connection, the construction of the protective layer, etc. Base or cushion 
construction is the key link to ensure that the seepage prevention effect, which must according to the design requirements to rod, roots and other organic impurities thoroughly clean, and there is no local bump phenomenon, using rammer or ram plate ram tight punning the base level. For composite geomembrane because of geomembrane and on both sides of the rise of arch dam, the construction is difficult guaranteeing the geomembrane enough protective layer on both sides. If on both sides of the cover thickness is larger, using the place rolling. Inclined wall geomembrane make cutting slope treatment according to design fault and then bedding fine aggregate, using word or roller compaction leveling. The structure of geomembrane anti-seepage are shown in fig.1.

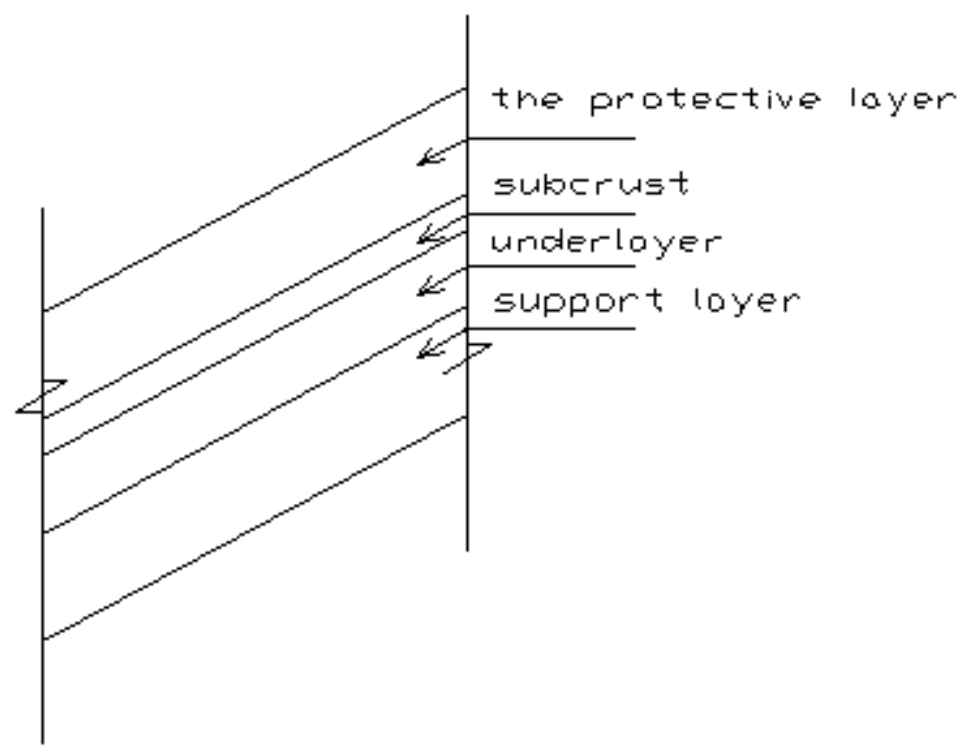

Fig 1 the structure of geomembrane anti-seepage

Upon the completion of the preparations and experience qualified, putting geomembrane flat at base level, surrounded by edges flattened keeps the straight. For composite geomembrane are mainly on its own to adapt to the deformation of the dam body, rather than rely on strength to resist deformation of dam body, therefore it should not be too tight when laying to evenly with small fold, making the geomembrane itself has certain elasticity to produce elastic limit deformation in construction to adapt to the deformation of dam body with the certain extend space at the same time. While the tile from the bottom up, from one end to the other end of the tile, so the air inside can squeeze film and lest produce small bubbles. Lay down area should be calculated $110 \%$ of the product. After putting the membrane, in a certain order synchronous forward of backfill layer, it can make the air in the membrane from the bottom of the film extrusion and allow the geomembrane in contact with the foundation, the cushion layer and consistent level, preventing the formation water seepage channel for geomembrane wrinkle. In the construction site tapping stone and other construction site may cause damage to the geomembrane all construction work is strictly prohibited.

\section{The analysis of the example}

A dam was built in 1955, homogeneous earth dam of $16 \mathrm{~m}$ height, dam crest elevation of $467.04 \mathrm{~m}$. Due to dam body since rolling false when building, especially the height of $457.18 \mathrm{~m}$ in the circumstances for the construction of flood dam filling, together with filter water blockage, it severely leaked, dam seepage escape point was just below 1.6-2.9 m, and the upstream water level below the height of $463.72 \mathrm{~m}$ large became wet. Because of the lack of appropriate protective layer 
of earth material and pressing time limit, the 2-3-0.18 mm thick polyethylene film and geotextiles combination anti-seepage was used. Membrane range from dam bottom to crest comprehensive laid, membrane area was $3600 \mathrm{~m}^{2}$. Geotextiles (weighing $300 \mathrm{~g} / \mathrm{m}^{2}$ ) per unit area was for plastic film covering layer, with $40 \mathrm{~cm}$ by $50 \mathrm{~cm} \times 6 \mathrm{~cm}$ concrete plate armor, concrete slab and small mutual built-in anti-skid teeth. It was experienced 7 years of operation. When the level of normal water level, dam area scattered leakage phenomenon disappear entirely. There is a good results have been achieved that potentiometric saturation line than before the renovation, a big drop in dam foundation seepage quantity is far less than specification requirements, experienced water several times change the protective layer without the slip deformation.

\section{Conclusion}

Practice has proved that composite geomembrane used in earth dam seepage control is feasible, especially for medium and small embankment dam seepage and dam heightening seepage control, which is a kind of very promising dam seepage control material. Anti-seepage geomembrane in deformation in the dam body is most can adapt to the displacement of dam body, just on the rigid anchor end local geomembrane exist large deformation. So research and explore should be make in practice more reasonable structure to adapt to local large deformation. For composite geomembrane is not on its own strength to resist the deformation of the dam to produce, but by ability to adapt to the deformation of dam body to improve its working reliability, so tensile rate problem should be play more attention on choosing and making membrane. Composite geomembrane anti-seepage structure in some projects achieving success proves that the geomembrane is a kind of ideal anti-seepage material.

Using geomembrane anti-seepage structure simplifies the structure of the seepage control facilities, improves the ability of engineering seepage control, shortens the construction period, reduces the project cost and improves the benefit of engineering. The geomembrane is commonly used in rock fill dam upstream dam and anti-seepage body, how to further widen the scope of its use and carry out the geomembrane materials design and construction monitoring and research, in the engineering application testing, scientific research, design, construction and management should be collaborative, promoting the earth dam seepage control technology and the development of earth and rock fill dam.

\section{References}

[1] JIANG jian-qiong. Construction engineering accident analysis and processing [M]. Beijing: China architecture \& building press, 2006.

[2] CHEN xi-zhe. Foundation at home and abroad and the cause of the accident analysis and processing [J]. Building technology. 1986, (12).

[3] XU you-jian. Water conservancy project geosynthetic material application technology [M]. Zhengzhou: The Yellow River water conservancy press. 2000, 10.

[4] ZHANG qi-yue. Earth and rockfill dam reinforcement technique [M]. Beijing: China water conservancy and hydropower press. 1999.

[5] FU zhi-gang. Geomembrane seepage and seepage analysis [J]. Water conservancy world. 2004 (2):15-17.

[6] CHEN shu-mei. The anti-seepage of geosynthetic materials in water conservancy engineering 
applications [J]. Ningxia agriculture and forestry science and technology. 2004, (6):43-44. 